\title{
Morphological and Chemical Characteristics of the Placer Gold Deposits from Meckin Dol, Locality of Borov Dol, Eastern Macedonia
}

\author{
VIOLETA K. STEFANOVA, University Goce Delčev, Štip \\ Faculty of Natural and Technical Sciences, R. Macedonia \\ Original scientific paper \\ UDC: $553.411(497.7)$ \\ TODOR S. SERAFIMOVSKI, University Goce Delčev, Štip, \\ Faculty of Natural and Sciences, R. Macedonia \\ GORAN K. TASEV, University Goce Delčev, Štip, \\ Faculty of Natural and Technical Sciences, R. Macedonia
}

\begin{abstract}
This paper presents the latest results from gold panning which was performed along the creek Meckin Dol. Research showed that the size of the tested gold aggregates ranges from 30 microns to about 600 microns, and the most frequently present form of gold aggregates was isometric - irregularform. The chemical composition of gold aggregates shows heterogeneity with an average gold content ranging from $74.15 \%-99.32 \%$, followed by silver with an average content of $0.3 \%-24.68 \%$, and an average copper content of 0.04 to $11.06 \%$. Other impurities such as $\mathrm{Fe}, \mathrm{Bi}$, Se, and Te are represented with content less than 1\%. In general it can be said that the examined gold aggregates, by their chemical composition, are characterized by high purity ranging from 750 to 996.
\end{abstract}

Key words: gold morphology, flatness index, chemical composition

\section{INTRODUCTION}

Copper and gold occurrences in the Borov Dol locality and its vicinity were known as early as the 19th century, which is reflected in the remains of old mining and archaeological artefacts found. Old gutters along the River Kriva Lakavica show the presence of gold in the recent alluvium of the River Lakavica.

In the period from 1952 until today, the Borov Dol site, its immediate vicinity and the connection of the Borov Dol with the River Kriva Lakavica, have been the subject of regional and detailed geological surveys and studies that resulted in the definition of the copper and gold porphyry type of deposit in the locality of Borov Dol and the presence of placer gold in the drainage systems of Borov Dol and along the River Kriva Lakavica. Contributions to these numerous studies are presented in the works of [6], [4], [11], [17], [2], [13], [14], [15], [19], [12]. The results of these tests instigated prospection research with det-

Author's address: Violeta Stefanova, University Goce Delčev, Faculty of Natural and Technical Sciences Štip, Goce Delčev 89

Paper received: 28.01.2014.

Paper accepted: 28.03.2014. ailed schlich prospection of certain parts of the primary and disintegrated mineralization material of the narrower and wider environment of the copper and gold deposits of the Borov Dol. The Meckin Dol creek was selected as the best subject for our tests and study after recognizing that this mineralized space, whose spring area is in direct contact with the primary copper and gold mineralization in the Borov Dol site, makes the disintegrated material a potential carrier of eluvial-proluvial-alluvial gold. Along the Meckin Dol creek, certain sampling points were selected for gold panning tests, where, during field work, a total number of 13 schlichs were sampled. The procedure for their further treatment is described in detail in the section on the methodology of the work. In the context of the above mentioned, and taking these facts into account in the framework of this paper, studies examining the rank of the physical characteristics, such as size and shape of the gold aggregates and their chemical composition, were undertaken.

\section{GELOGICAL CHARACTERISTICS OF THE TERRAIN}

The Borov Dol deposit is part of the mining region Bucim-Damjan-BorovDol, that is, it occupies the 
southern parts. The metallogeny of this ore region is closely related to the evolution of the Tertiary magmatism represented by sub-volcanic-volcanic facies of andesite, latites, quartz latites, trachyrhyolites and so forth, which are the product of intermediate to acid calc-alkaline magmatism. Numerous interesting mineralizations of $\mathrm{Cu}, \mathrm{Fe}, \mathrm{Pb}-\mathrm{Zn}$ as well as $\mathrm{Au}$ mineralizations are related to this magmatism. The geological structure (Figure 1) of the Borov Dol deposit, which is quite complex, contains Paleogene, Neogene and volcanogenic-sedimentary and volcanic rocks [11], [17], [12].

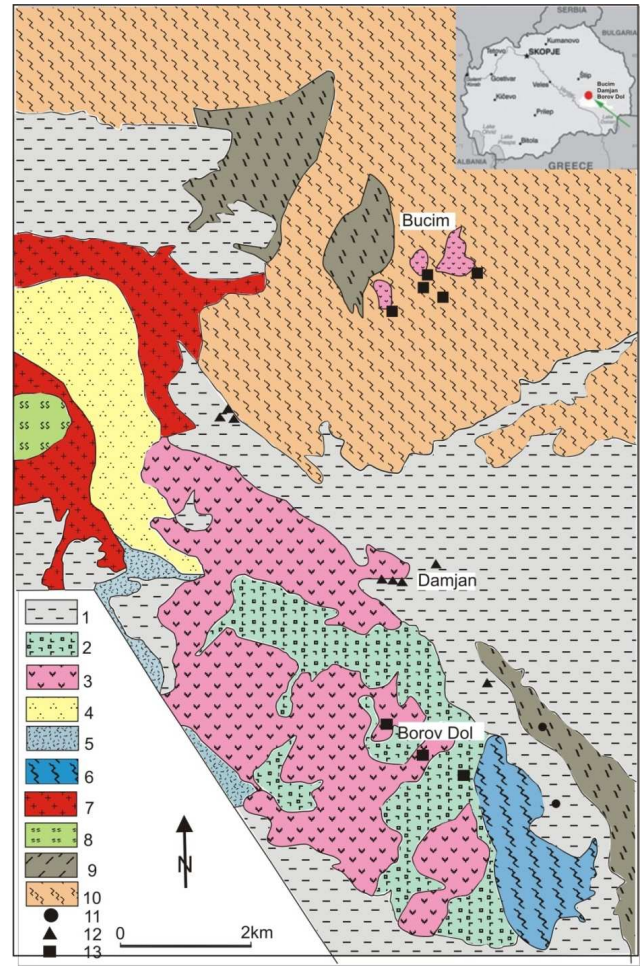

Figure 1 - Geological setting from Bucim-DamjanBorovDol ore district (Denkovski, 1995, supplment, Stefanova, 2005): 1. Paleogene, neogene quarter sediments, 2. Pyroclasts, 3. Andesite and latite, 4. Cretaceus flusch, 5. Carbontites, 6. Carbonate-schists series, 7. Granites, 8. Serpentinites, 9. Micasists, 10. Gneiss, $11 . P b-Z n$ vein type of mineralization, 12. $\mathrm{Fe}-$ skarns type of mineralization, 13. Porphyry type of mineralization

Paleogene sediments occupy a large part of the terrain and are represented by conglomerates, Paleogene flysch and series of tuffites and sands. Conglomerates are heavily modified and built mostly of fragments of gneiss and quartz. Flysch facies are built of thin layers of fine-grained and large-grained sandstone and conglomerates. The volcanogenic sediment series is built of sandstones, marly sandstone and li- mestone, and pelitic tuffs and tuffites. Tuffs are determined as andesite and their presence indicates that the volcanic activity is synchronous with sedimentation of Paleogenic sediments. Neogenic sediments, which are represented by conglomerates, are built of heterogeneous material dominated by pieces of quartz, crystalline shale and Paleogenic sediments. Magmatic rocks are represented by volcanic and subvolcanic facies of latites, quartz latites and andesites. Andesites in turn, depending on the degree of change and ore amount are divided into: propilytized andesites, hydrothermally altered andesites, hydrothermally altered and mineralized andesites and andesite lava. Effusive rocks occur in the form of outcrops and lava. Large porphyritic propilytized andesites, that is, latites and quartz latites, that occupy most of the terrain, are hydrothermally altered and mineralized. Latites and quartz latites are products of the older phase, hacked with dark grey fine-grained biotite amphiboleandesite which, in the form of a neck, are imprinted on the central part of the Borov Dol circular structure.

\section{METHODS AND MATERIALS}

Gold prospection was applied, from which material of about $10-15 \mathrm{~kg}$ from each sampling location was taken. After panning, magnetic separation of the magnetic fraction was undertaken manually. Both fractions obtained were observed under binoculars. The gold aggregates found were separated manually and subjected to further study.

To determine the morphological features of the gold - primarily the roundness, flatness, and serration of the grains - scanning electron microscopy (SEM) was used. This type of analysis allowed the length of the transport and nature of the environment in which the pan material was deposited to be determined. The SEM study was undertaken in the electron microscopy laboratory within the Faculty of Stip University, Macedonia.

Analyses were performed on a VEGA3 LMU.

The etalons were from TESCAN. The specific operating conditions were

- Tension: $20 \mathrm{keV}$

- Test Method: EDS

- Type of analysis: Quantitative

- X-act: $10 \mathrm{~mm}^{2}$ (Slicon Drift detector)

- Max resolution: $125 \mathrm{EV}$

- Resolution of $\mathrm{MnK} \alpha, \mathrm{FK} \alpha, \mathrm{CK} \alpha$ : according to ISO 15632:2012

\section{RESULTS AND DISCUSSION}

Studies were performed along the Meckin Dol over a length of about $0.6 \mathrm{~km}$ (Figure 2). 


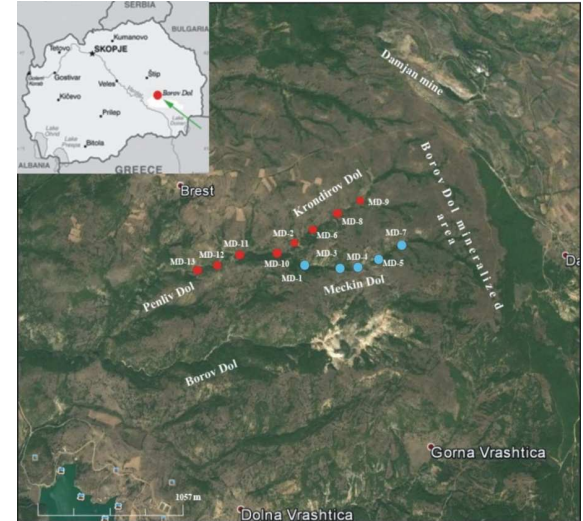

Figure 2 - Locationof sampling sites on shlich samples from locality MeckinDol

Out of the total of 13 samples, 5 samples were taken for more detailed processing. We found a total of 56 gold grains of different shapes and sizes (Table 1 ). The second mineral represented is chalcopyrite which is the copper bearing mineralization in this locality. Another metallic mineral in the material is pyrite, and in some galenite was significantly represented. Less prevalent are sphalerite, malachite, azu- rite and specularite. The non-metal minerals, zircon, mica, and epidote are present.

Table 1. Results from pan material investigations

\begin{tabular}{||l|l|}
\hline Sample No. & Number of gold agregates \\
\hline MD-1 & 5 \\
\hline MD-3 & 37 \\
\hline MD-4 & 3 \\
\hline MD-5 & 4 \\
\hline MD-7 & 4 \\
\hline
\end{tabular}

The most important mineral from this prospection is gold. It is characterized by a beautiful yellow colour and it has various sizes. Gold is found in elongated, dendritic irregular shapes and less frequently in spherical shapes. In order to precisely define and determine the size and shape of the gold aggregates, detailed SEM investigations were undertaken (Fig. 3). From these examinations, it can be said that an isometric form prevails (Fig. 3f) while elongated gold aggregates (Figure $3 \mathrm{a}$ and $3 \mathrm{~b}$ ), spherical shapes (Figure $3 \mathrm{~b}$ and $3 \mathrm{c}$ ) and plate forms were also found (Figure 3e).

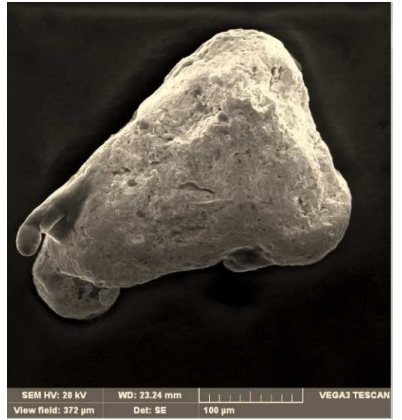

a-elongated irregular gold grain

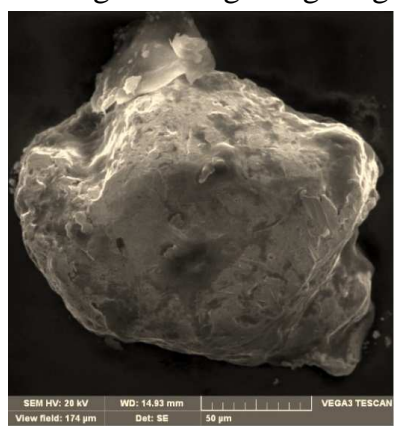

d-rounded form
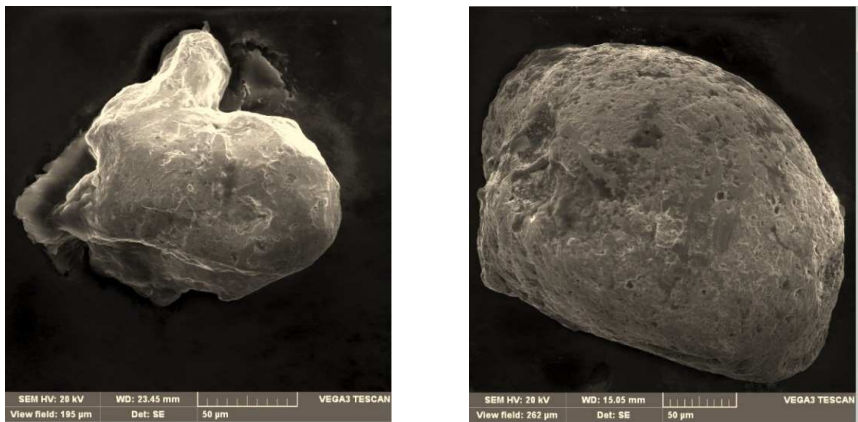

b-elongated irregular gold grain c-Aggregate with spherical form

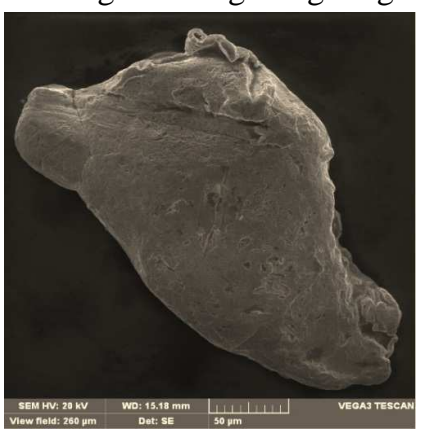

e- Aggregate with platy form

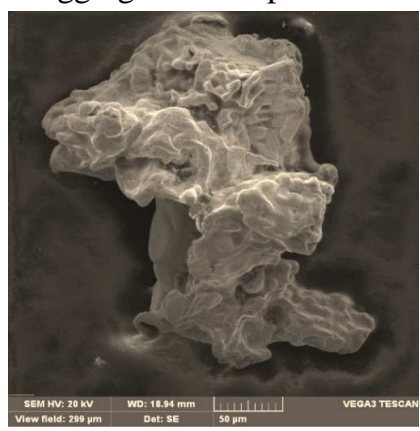

$\mathrm{f}$-isometric gold grain

Figure 3 - Morphological forms of matching gold aggregates of Meckin Dol, Borov Dol locality

The physical characteristics of the gold, such as the size of the grains, depend on the type of primary mineralization, type and length of transport and the erosion processes to which the terrain was subjected [8]. The morphology of the gold aggregates as a function of the length of transport can serve as an effective tool in determining the distance from the main source, that is, the identification of the proximity of the primary gold source. Apart from the form and shape of the gold aggregates as a real indicator of length of transportation, the flatness index can be used, which is calculated by the equation: $(L+b) / 2 t$, 
where $\mathrm{L}$ is the grain length, $\mathrm{b}$ is the width, and $\mathrm{t}$ is the breadth, although the degree of roundness and the appearance of edges are also a good indicator ([16]). Studies of the forms of gold aggregates from the tested locality show that irregular isometric shapes prevail in the vicinity of the primary source, while downstream from the creek, as a result of transport, these forms are lost, that is, the grains are elongated and rounded.

At a distance of up to $50 \mathrm{~m}$ from the primary mineralization, almost identical shapes as well as primary gold prevail. At a distance of 50 to $300 \mathrm{~m}$ se- condary grains become elongated, they even become triangular in shape with the appearance of small voids on the grain surface. At a distance greater than $300 \mathrm{~m}$ the primary shapes of the grains are lost ([16] and [9]). The flatness index of the examined gold aggregates from the Meckin Dol creek ranges from 1.05 to 3.27. Based on morphological characteristics, form, shape, external appearance, and flatness index, two groups of gold aggregates can be distinguished (Table 2 ). The aggregates up to $50 \mathrm{~m}$ belong in the first group, and the gold aggregates from 50 to $300 \mathrm{~m}$ belong in the second group.

Table 2. Morphological characteristics of Au grains associated with distance from source

\begin{tabular}{|l|l|l|l|l|l|}
\hline $\begin{array}{l}\text { Distance } \\
\text { to source }\end{array}$ & General shape, outline-surface of gold aggregates \\
\hline Flatness index 1-2 & \\
\hline Flatness index 2.1-3.3 $50 \mathrm{M}$ &
\end{tabular}

The first group of grains (Table 2) is characterized by a well preserved original form: square to rectangular shapes, angular edges. The general shape of the grains is irregular. They can often be found in the elongated shapes.

The flatness index ranges from 1 to 2 . The second group is represented by aggregates with a flatness index of 2.1-3.3 and are characterized by slightly elongated shapes. The general appearance is represented by a relatively regular shape.

It could be said that the external shape of the studied grains of the locality varies widely, which, according to [18], is due to the fact that primary grains show a wide variety of initial shapes.

Such characteristics suggests that this gold probably has similar characteristics as the primary gold, [10] and that it has not suffered long transportation. Square or flat shapes as well as elongated shapes found in the test locality are a feature of primary gold that typically occurs in such shapes, although it sometimes may occur in square to rectangular but very irregular shapes with expressed sharp contours and edges on the grains [8], [16], [7], [9].

Beside the shape, analyses of the chemical composition of the gold aggregates were undertaken, which showed that it was native gold characterized by high purity.

According to [20] the gold with a purity of 900950 is called high grade gold, and the gold whose purity ranges from 800-899 belongs to the group of moderate grade gold. Given this grouping, it can be said that (Table 3) most of the tested gold aggregates belong to the group of high grade gold where the gold content ranges from $92 \%$ to a maximum of $99 \%$, and a smaller amount with lower purity where the gold content ranges from $71 \%$ to $84 \%$ 
V. STEFANOVA at al. MORPHOLOGICAL AND CHEMICAL CHARACTERISTICS OF THE PLACER...

Table 3. Chemical composition of gold aggregates-Meckin Dol, Borov Dol locality (\%)

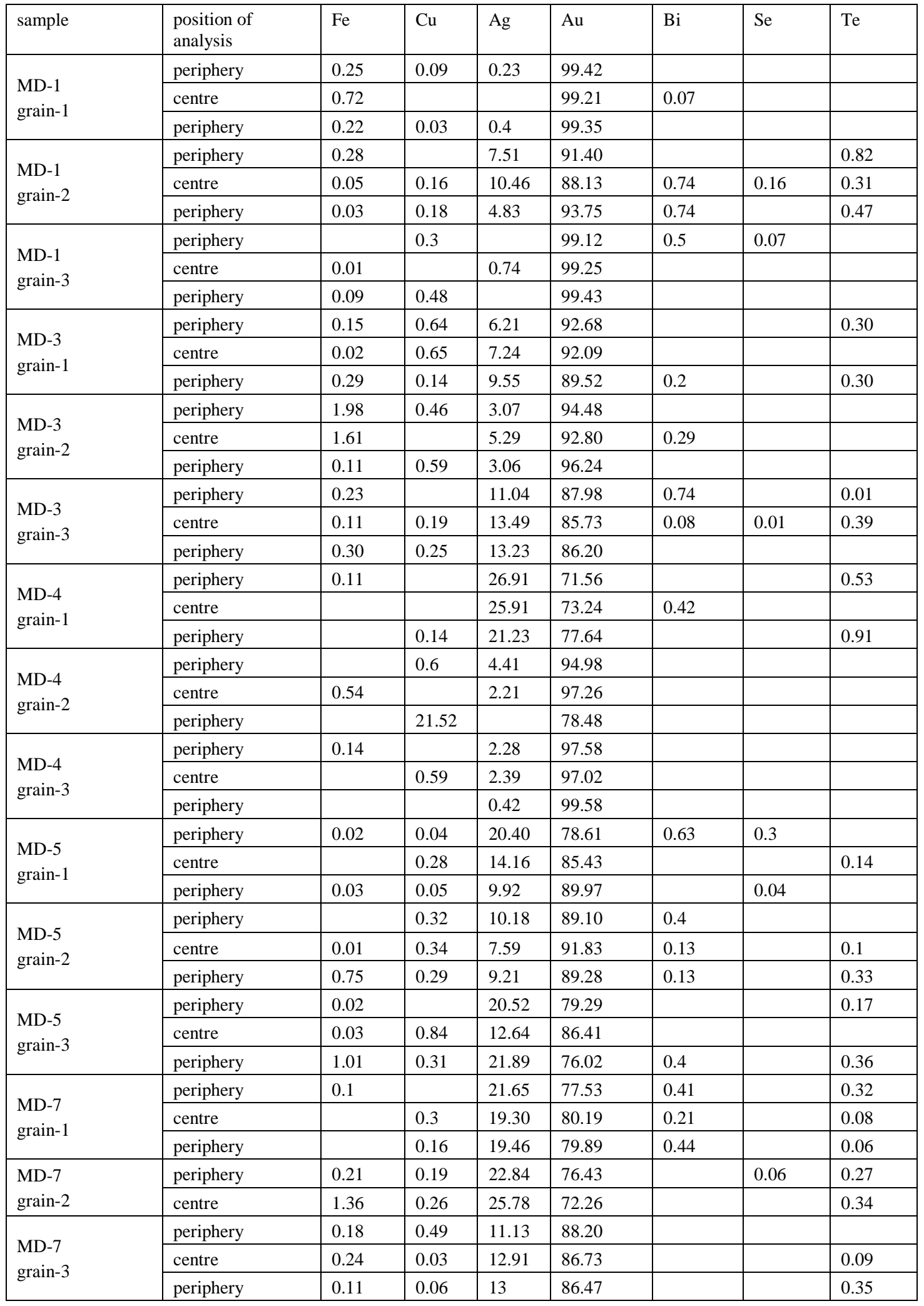


Examination of the gold aggregates was undertaken in peripheral areas and one analysis in the central area in order to illustrate whether there was zonality in the chemical composition. As the dominant admixture in gold aggregates, silver is present in the rank ranging from $<1 \%$ to $26.91 \%$. Fig. 4 shows a histogram displaying the silver content in the tested gold aggregates. In alluvial gold, the silver content can vary from 32 to $50 \%$ (with an average fineness of 630), with other elements not exceeding $1 \%$ [1].

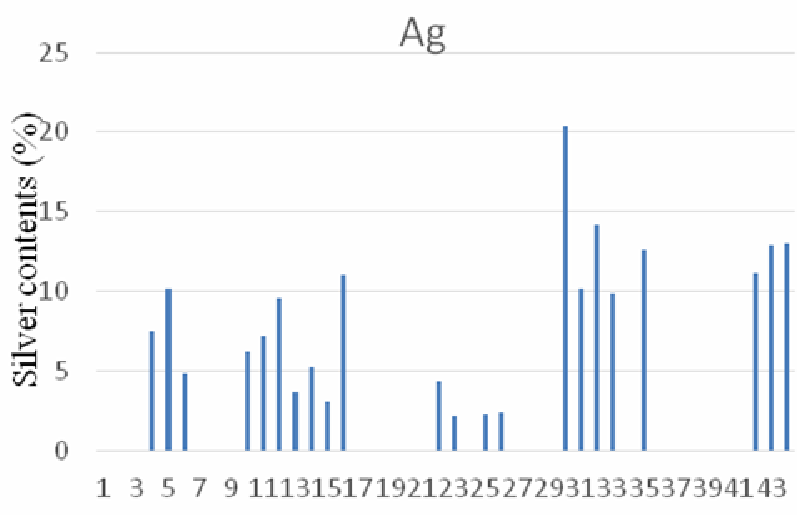

Number of measurements

Figure 4 - Histogram display the contents of the tested silver gold aggregates of Meckin Dol

In addition, regularity in the silver content was not noticed. Some of the central gold aggregates are richer in silver than those from the periphery, which can be seen in Table 3 (MD-1 grain 2, MD-7 grain 2) while in others reverse zonality is observed - the central gold aggregates are poorer in silver than those from the periphery. In most of the tested gold aggregates there is no regularity in terms of silver content.

Studies of the relationship between the composition of gold and the length of transportation showed that there is no change in the microchemical record of the alluvial gold during transportation ([3]).

As for other ingredients, the presence of $\mathrm{Fe}, \mathrm{Cu}$, $\mathrm{Bi}, \mathrm{Se}$, and $\mathrm{Te}$ is determined. Iron content ranges from 0.01 to $1.98 \%$; copper content from 0.03 to $0.84 \%$ and other impurities, such as $\mathrm{Bi}, \mathrm{Se}$, and $\mathrm{Te}$, are under-represented and in some aggregates they are even absent. Based on these data, it can be said that gold aggregates in general have a homogeneous composition which leads to the assumption that gold aggregates derive from one source ([5]).

\section{CONCLUSION:}

The results of the investigations into the morphology of gold aggregates and the flatness index 12, from the locality of Meckin Dol suggests that there is a primary deposit in the immediate vicinity which has disintegrated to produce the material. The size of the gold aggregates found ranges from 30 to about 600 microns. Based on tests it was determined that gold aggregates commonly occur in irregular iso- metric form, then in a round-spherical shape, and in the shape of plates. The irregular shape is most common.

Studies of the chemical composition showed that the gold is characterized by high purity, which ranged from 750 to 996 . Of all the impurities, the silver content is the greatest from $<1 \%$ to $26.91 \%$. As for the other ingredients, the $\mathrm{Fe}, \mathrm{Cu}, \mathrm{Bi}, \mathrm{Se}$, and $\mathrm{Te}$ content was found to be low.

\section{REFERENCES}

[1] Bahna B, Smirnov A, Chovan M. \& Bakos F River transport - induced hanges in chemical composition of alluvial gold (documented on localities of Western Carpathians).In:Geol.Carpath. (Bratislava), 53 (spec. iss.), $105-107.2002$

[2] Bogoevski, K., Gold in Macedonia-geology, metalogenic, features, ore occurrences, gold ore deposits and their evaluation. Special Issue No. 7 pp. 249, 1998

[3] Chapman R J, Leake R C, Moles NR, Earls G, Cooper C, Harington K, Berzins R, The aplication of Microchemical Analysis od Alluvial Gold Grains to the Understanding of Complex Local and Regional Gold Mineralizaction: A case Study in the Irish and Scottish Caledonides, Economic Geology, Vol 95. pp. 1753-1773, 2000

[4] Denkovski, G., Stefanova, G., Bandilov, L., Izvestaj za slihovskata prospekcija I metalogenetskata prospekcija na lakavickiot region. Strucen fond Bucim, 1995 
[5] Florencia M, Southam G, Graig R James, Galliski M A Morphological and Chemical study of placer gold from the San Luis range, Argentina.The Canadian Mineralogist, Vol. 42 pp. 169-182, 2004

[6] Ivanov, T., Metalogenetska studija na rudniot reon Bucim-Damjan-Borov Dol. Strucen fond Bucim, 1982

[7] McClenaghan MB Indicator mineral methods in mineral exploration; Geological Society ofLondon, v. 5 , p. 233-245, 2005

[8] Mudaliar1 GG, Richards1 JP, Eccles DR Gold, Platinum and DiamondPlacer Deposits in AlluvialGravels, Whitecourt, Alberta, EUB/AGS Special Report 089 (May 2007) pp 35, 2007

[9] Nakagawa M, Santosh M, Nambiar CG, Matsubara C Morphology and chemistry ofplacer gold from Attapadi Valley, southern India; Gondwana Research, v. 8, no. 2, p. 213-222, 2005

[10]Петровскаја Н В Самородное золото. М. Недра, Москва, стр. 347, 1973

[11]Serafimovski, T., Metalogenija na zonata Lece-Halkidik, PhD, Stip, pp 380, 1990

[12]Serafimovski. V., Stefanova, V., Volkov. A. V., 2010: Dwarf Copper-Gold Porphyry Deposit of the Buchim-Damjan-Borov Dol Ore District, Republic of Macedonia (FYROM). Geologiya Rudnykh Mestorozhdenii, Vol. 52, No3, pp 203-220.

[13]Stefanova, V., Eluvijalno-deluvijalni pojavi na zlato povrzani za tercieren magmatizam vo R. Makedonija. Doktoska disertacija, pp.198, 2005

[14]Stefanova, V., Kovacev, V., Mladenov, V., Stanimirova, C., Eluvial-alluvial gold from gold-copper occurrence Borov Dol (R. Macedonia). Part II: Mineralogy of gold and stream sediments. Review of the Bulgarian Geological Society, vo. 68, part 1-3, pp. 77-91, 2007

[15]Stefanova, V., Serafimovski, T., Tasev, G. and von Quadt, A., Placer gold prospecting around the Tertiary occurrences in the Republic of Macedonia. (Eds. A. von Quadt \& T. Serafimovski) Diversity of copper and gold deposits in the Eastern Europe Balkan, Carpathian and Rhodopean belts: tectonic, magmatic and geochronological investigations; SCOPES Project-International Conference, May 29 June 02, 2012 - Izgrev Hotel, Stip, Macedonia, pp. 33,2012

[16]Townley BK, Herail G, Maksaev V, Palacios C, de Parseval P, Sepulveda F, Orellana R, RivasP, Ulloa $\mathrm{C}$ Gold grain morphology and composition as an exploration tool: applicationto gold exploration in covered areas; Geological Society of London, v. 3, p. 29-38, 2003

[17]Tudzarov, N., Metalogenija na naogalisteto na bakar Borov Dol, doktorska disertacija, Stip pp. 195, 1993

[18]Utter T Rounding of Ore Particles from the Witwatersrand Gold and Uranium Deposit (South Africa) as an Indicator of their Detrial Origin, Journal of Sedimenatry Petrology, V., 50, № 1, pp 71-76 (од Knight,et. all., 1994), 1980

[19]Volkov, A.V., Stefanova, V., Serafimovski, T., Sidorov, A.A. R., Native Gold of the Porphyry Copper Mineralization in the Borov Dol Deposit (Republic of Macedonia). Doklady Earth Sciences, Vol. 422, No. 7, pp. 1013-1017, 2008

[20]Zaharova, E.M., MinerologiaRosipei, Nedra, Moskva pp.191, 1994.

\section{REZIME}

\section{MORFOLOŠKE I HEMIJSKE KARAKTERISTIKE NANOSNOG ZLATA SA MEČKIN DOLA, LOKALITET BOROV DOL, ISTOČNA MAKEDONIJA}

U radu su prikazani najnoviji rezultati šlihovske prospekcije zlata na lokalitetu Mečkin Dol. Istraživanja su pokazala da je veličina ispitivanih agregata zlata od 30 do oko 600 mikrona, kao i da je najčešći oblik njihovog pojavljivanja izometrično-nepravilni. Hemijski sastav zrna zlata ukazuje na njihovu heterogenost. Prosečni sadržaj je 74.15 - 99.32\%, srebra od 0.3-24.68\% i bakra od 0.04 do $11.06 \%$. Ostale primese ( $\mathrm{Fe}, \mathrm{Bi}$, Se, Te) su zasupljene u količini manjoj od 1\%. Generalno, može se zaključiti da su ispitivani agregati zlata hemijski cisti, na nivou od 750 do 996.

Ključne reči: morfologija zlata, indeks spljeskanosti, hemiski sastav 